by no longer screening patients in these two categories. Our results, however, question the validity of screening to protect dentists. A more logical approach would be to encourage vaccination of all staff at risk of infection with $\mathrm{HBV}$ at the earliest possible opportunity and to assume that all patients are a potential source of infection. We have recently adopted this policy.

1 Schiff ER, de Medina M, Woodman S, Katz B, Kline S. VA co-operative study on hepatitis and dentistry. Hepatology 1982;2:688.

2 Epstein JB, Bucher BK, Bouchard S. Hepatitis B and Canadian dental professionals. Fournal of the Canadian Dental Association 1984;7:555-9.

3 Scully C. Hepatitis B: an update in relation to dentistry. Br Dent $\mathcal{J}$ 1985;159:321-8.

4 Linneman CG, Hegg ME, Raymundo N, Schiff GM. Screening hospital patients for hepatitis B surface antigen. Am $\mathcal{J}$ Clin Pathol 1977;67:257-9.

5 Mazel JA, Heijtink RA, Schalm SW. Gecomineerde passieve en actieve immunisatie van zuigelingen van HBsAg moeders. Ned Tijdschr Geneeskd 1985;129:150.

(Accepted 15 May 1987)

Liver Unit and Department of Primary Dental Care, King's College Hospital and School of Medicine and Dentistry, London SE5 8RX

HEATHER M SMITH, BSC, senior biochemist

GRAEME J M ALEXANDER, MRCP, honorary lecture

WARREN BIRNBAUM, BDS, FDSRCS, associate specialist

ROGER WILLIAMS, MD, FRCP, director, liver unit

Correspondence to: Dr Williams.

\section{Does nifedipine ameliorate cyclosporin A nephrotoxicity?}

Nephrotoxicity is a serious disadvantage of cyclosporin A and may lead to irreversible loss of renal function. ${ }^{1}$ Recent evidence suggests that it may be a haemodynamic phenomenon due to intrarenal vasoconstriction. ${ }^{23}$ Studies in animals show that the calcium channel blocker nifedipine may reverse the effects of long term treatment with cyclosporin. ${ }^{4}$ We report the influence of nifedipine on graft function in a retrospective study of renal transplant recipients given cyclosporin.

\section{Patients, methods, and results}

We reviewed 106 patients who had stable transplant function at least three months after grafting and were taking cyclosporin. Cyclosporin (usually combined with low dose prednisolone) was given in maintenance doses of $5-8 \mathrm{mg} / \mathrm{kg} / \mathrm{day}$, and trough whole blood cyclosporin concentrations were measured by high pressure liquid chromatography. Renal function was assessed by measuring the serum creatinine value. Hypertension (diastolic blood pressure $\geqslant 95 \mathrm{~mm} \mathrm{Hg}$ requiring drug treatment) was usually treated by $\beta$ blockers combined with vasodilators; since 1984 prazosin and hydralazine had increasingly been superseded by nifedipine. Choice of blood pressure treatment was based on individual clinical decision. All rejection episodes had been confirmed histologically.

Hypertension was present in $90(85 \%)$ of the patients taking cyclosporin (compared with $54 \%$ of our patients receiving azathioprine; $p<0.001$ ). For further analysis patients receiving nifedipine $(n=58)$ were separated from those who were hypertensive but not taking nifedipine $(n=32)$ and from the normotensive group $(n=16)$ (table). The three groups did not differ in distribution of primary renal disease leading to end stage renal failure, incidence of bilateral nephrectomy, and use of prednisolone.

Those receiving nifedipine had their grafts for a shorter mean period $(\mathrm{p}<0.001)$, which was reflected in a significantly higher mean dose of cyclosporin $(p<0.02)$ and higher whole blood concentrations of the drug $(p<0.05)$. Despite this, renal function was better in those receiving nifedipine compared with hypertensive patients not receiving nifedipine (serum creatinine concentration $153(\mathrm{SEM} \mathrm{10)} v 183(13) \mu \mathrm{mol} / \mathrm{l} ; \mathrm{p}<0.05)$ and similar to that in normotensive patients taking cyclosporin $(154(11) \mu \mathrm{mol} / \mathrm{l})$. Blood pressure was controlled to an equivalent, acceptable degree in both hypertensive groups.

Rejection was infrequent during treatment with cyclosporin, only 33 of the 106 patients having suffered a rejection episode. More patients in group 2 had suffered rejection episodes $(14 / 32 ; 43.8 \%)$ compared with group $3(15 / 58 ; 25 \cdot 9 \%)$ and group $1(4 / 16 ; 25 \%)(p<0.05)$. Analysis of the 71 patients who had never had a rejection episode, however, showed that the serum creatinine concentration among those receiving nifedipine was still lower than in hypertensive patients not receiving nifedipine $(141(6.8) v 175(22) \mu \mathrm{mol} / \mathrm{l} ; \mathrm{p}<0.05)$ and comparable to that in normotensive patients.

\section{Comment}

This retrospective analysis has identified a cohort of renal transplant recipients receiving nifedipine for cyclosporin related hypertension who, owing to shorter graft duration, high cyclosporin dosage, and higher blood concentrations of cyclosporin, would have been at risk. of more severe cyclosporin nephrotoxicity. These patients, however, had better graft function than equivalent hypertensive patients receiving other drug treatment. This finding was sustained even when the possible influence of previous graft rejection was excluded.

Though cyclosporin may produce irreversible loss of renal function, ${ }^{1}$ the more characteristic pattern of a raised serum creatinine concentration rapidly falling when cyclosporin dosage is reduced suggests a haemodynamic abnormality. Studies in rodents suggest that cyclosporin produces intrarenal vasoconstriction, ${ }^{2}$ and isotope studies in patients with renal transplants have shown increased renal vascular resistance which is corrected with a parallel fall in serum creatinine concentration when cyclosporin is replaced by azathioprine. $^{3}$

The role of vasodilator agents to reverse cyclosporin nephrotoxicity has not been studied in man. Animal studies suggest that nifedipine is superior to $\alpha$ adrenergic blockade, converting enzyme inhibition, and manipulation of prostaglandins in reversing cyclosporin induced intrarenal vasoconstriction. ${ }^{4}$ It is not clear if this is a specific effect of calcium channel blockade, though there is some evidence that calcium channel blockers prevent cyclosporin uptake by kidney cells in culture.

Nifedipine appears to be of potential value as a cyclosporin nephroprotective agent, and further prospective haemodynamic studies are justified.

1 Myers BD, Ross J, Newton L, Luetscher J, Perloth M. Cyclosporine-associated chronic nephropathy. N Engl f Med 1984;311:699-705.

2 Dieperink H, Leyssac P, Starklint H, Kemp E. Nephrotoxicity of cyclosporin A. A lithium clearance and micropuncture study in rats. Eur $\mathcal{X}$ Clin Invest 1986;16:69-77.

3 Curtis JJ, Luke RG, Dubovsky E, et al. Cyclosporin in therapeutic doses increases renal allograft vascular resistance. Lancet 1986:0ï:477-9.

4 Dieperink H, Leyssac P, Starklint H, Jorgensen KA, Kemp E. Antagonist capacities of nifedipine captopril, phenoxybenzamine, prostacyclin and indomethacin on cyclosporin $\mathrm{A}$ induced impairment of rat renal function. Eur 7 Clin Invest 1986;16:540-8.

5 Nagineni CN, Yamagawa N, Musra B, Lee DBN. Cyclosporin A-calcium channels interaction a possible mechanism for nephrotoxicity. Transplant Proc 1987;19:1358-62.

(Accepted 26 May 1987)

Departments of Nephrology and Surgery, Leicester General Hospital, Leicester LE5 4PW

J.FEEHALLY, DM, MRCP, senior registrar in nephrology

J WALLS, FRCP, consultant nephrologist

N MISTRY, BSC, MPHIL, senior medical laboratory scientific officer

T HORSBURGH, PHD, principal biochemist

J TAYLOR, FRCS, transplant fellow

P S VEITCH, FRCS, consultant surgeon

P R F BELL, MD, FRCS, professor of surgery

Correspondence to: Dr Feehally, department of nephrology.

Characteristics of normotensive and hypertensive renal transplant recipients and influence of nifedipine. Mean values expressed with SEM in parentheses

\begin{tabular}{|c|c|c|c|c|c|c|c|c|}
\hline . & No & Age (years) & $\begin{array}{l}\text { Graft duration } \\
\text { (months) }\end{array}$ & $\begin{array}{c}\text { Mean arterial } \\
\text { blood pressure } \\
(\mathrm{mm} \mathrm{Hg})\end{array}$ & $\begin{array}{l}\text { No }(\%) \text { of patients } \\
\text { not receiving } \\
\text { corticosteroids }\end{array}$ & $\begin{array}{c}\text { Cyclosporin dose } \\
(\mathrm{mg} / \mathrm{kg} / \text { day })\end{array}$ & $\begin{array}{l}\text { Whole blood } \\
\text { cyclosporin concentration } \\
(\mu \mathrm{g} / \mathrm{l})\end{array}$ & $\begin{array}{l}\text { Serum } \\
\text { creatinine } \\
(\mu \mathrm{mol} / 1)\end{array}$ \\
\hline $\begin{array}{l}\text { Group 1: normotensive } \\
\text { Group 2: hypertensive, not taking nifedipine } \\
\text { Group 3: hypertensive, taking nifedipine }\end{array}$ & $\begin{array}{l}16 \\
32 \\
58\end{array}$ & $\begin{array}{l}49 \cdot 3(3 \cdot 8) \\
39 \cdot 1(2 \cdot 2) 5 \\
42 \cdot 5(2 \cdot 0)\end{array}$ & $\begin{array}{l}21 \cdot 8(3 \cdot 0) \\
28 \cdot 9(2 \cdot 8) \\
16 \cdot 7(1 \cdot 4)^{\star \star}\end{array}$ & $\begin{array}{r}98 \cdot 3(2 \cdot 9) \\
101 \cdot 5(2 \cdot 1) \\
97 \cdot 4(1 \cdot 2)\end{array}$ & $\begin{array}{r}3(19) \\
6(19) \\
10(17)\end{array}$ & $\begin{array}{l}5 \cdot 7(0 \cdot 4) \\
5 \cdot 7(0 \cdot 2) \\
7 \cdot 2(0 \cdot 4) t\end{array}$ & $\begin{array}{l}293(39) \\
270(22) \\
327(17)^{\star}\end{array}$ & $\begin{array}{l}154(11) \\
183(13) \mathrm{Ht} \\
153(10)\end{array}$ \\
\hline
\end{tabular}

${ }^{\star} \mathrm{p}<0.05$ compared with group 2.

$\star p<0.001$ compared with group 2.

tp<0.02 compared with groups 1 and 2 .

$+\mathrm{p}<0.05$ compared with groups 1 and 3.

Sp<0.02 compared with group 1 .

(Differences compared by Student's $t$ test.) 